\title{
Teaching congenital heart disease: A new era?
}

\author{
Ziv Beckerman, MD, and Carlos M. Mery, MD
}

\author{
From Congenital Heart Surgery, Texas Children's Hospital, and Michael E. DeBakey Department of Surgery, \\ Baylor College of Medicine, Houston, Tex. \\ Disclosures: Authors have nothing to disclose with regard to commercial support. \\ Received for publication Feb 11, 2017; accepted for publication Feb 15, 2017; available ahead of print March 28, \\ 2017. \\ Address for reprints: Ziv Beckerman, MD, Congenital Heart Surgery, Texas Children's Hospital, 6621 Fannin St, \\ Houston, TX 77030 (E-mail: bxziv@texaschildrens.org). \\ J Thorac Cardiovasc Surg 2017;153:1541 \\ $0022-5223 / \$ 36.00$ \\ Copyright (c) 2017 by The American Association for Thoracic Surgery \\ http://dx.doi.org/10.1016/j.jtcvs.2017.02.045
}

Surgical teaching and training are the mainstays of surgery. As Yoo and colleagues ${ }^{1}$ so clearly point out, we require much improvement in our teaching and training methods.

The trainees in adult and congenital cardiothoracic surgery programs are provided with limited operative experience. ${ }^{2}$ Although hands-on surgical training is necessary, it is extremely difficult to provide without compromising patient safety.

Fraser $^{3}$ depicts a most-pertinent point regarding risks of surgical teaching and training in a recent article:

In the current era, the historical reference to a surgical "learning curve" for the arterial switch operation is no longer practically or ethically acceptable. In this context, it is very important for the young surgeon in training or early in his or her surgical career to have appropriate mentoring and senior surgeon support, guidance, and where necessary, direct technical assistance.

This is true for most or all of the current operations in congenital heart surgery.

Halsted, ${ }^{4}$ who is among the most influential and innovative surgeons in American medical history, had countless accomplishments and contributions to medicine. Perhaps his greatest contribution was his system for surgical training. The average term of service for a Halsted surgical trainee who succeeded to the chief residency position in the hospital was 8 years -6 years as an assistant and 2 years as the house surgeon.

Although years have passed since Halsted established these principles, not much has changed. Today, we still rely on exposure to graduated clinical experience in operating rooms during several years of residency. ${ }^{4}$ In many other professions, the methodology of training has changed and advanced to include various simulators and computer-based learning systems, but the medical-surgical field lags behind.

Yoo and colleagues ${ }^{1}$ embarked on a mission to study this important topic, and assessed the utility of surgical training using 3-dimensional (3D) print models. In accordance with their experience and findings, they suggest that 3D print models can improve surgical skills, improve exposure,

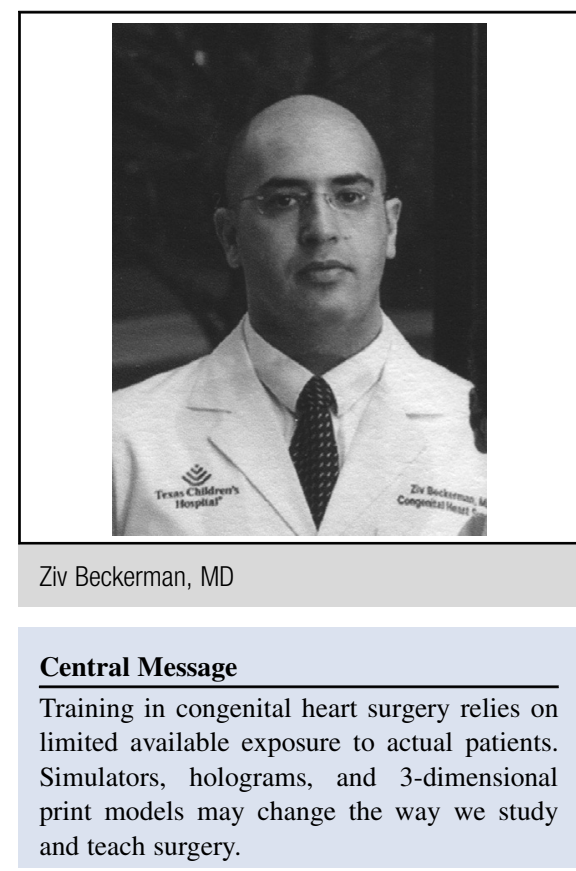

See Article page 1530 .

decrease the risk to patients' health and life during the learning period, and allow standardization of surgical procedures throughout the country and even perhaps the world. Some of these statements still require corroboration.

3D print models might also be useful for better surgical planning and evaluation of patients with complex intracardiac anatomy. We still find ourselves debating, occasionally, what is the best surgical repair or reconstruction for a patient. 3-D models or simulators might be able to provide us with better answers.

There is still a way to go, and surgical simulators require improvement. The 3D printing models are not perfect, and image quality and printing quality still require improvement. Nevertheless, it is my true belief that surgical simulation and model learning will continue to move forward, thanks to continuous work and effort such as that put into this article.

\section{References}

1. Yoo SJ, Spray T, Austin EH III, Yun TJ, van Arsdell GS. Hands-on surgical training of congenital heart surgery using 3-dimensional print models. J Thorac Cardiovasc Surg. 2017;153:1530-40.

2. Chu D, Vaporciyan AA, Iannettoni MD, Ikonomidis JS, Odell DD, Shemin RJ, et al. Are there gaps in current thoracic surgery residency training programs? Ann Thorac Surg. 2016;101:2350-5.

3. Fraser CD Jr. The neonatal arterial switch operation: how I teach it. Ann Thorac Surg. 2016;102:681-4.

4. Halsted WS. The training of the surgeon. Bull Johns Hopkins Hosp. 1904;15: $267-75$. 